ÉGYPTE monde arabe

\section{Égypte/Monde arabe}

1 | 2005

Le shaykh et le procureur

\title{
What happened? Stories, judgements and reconciliations
}

\section{Barbara Drieskens}

\section{(2) OpenEdition \\ 12 Journals}

Édition électronique

URL : https://journals.openedition.org/ema/1047

DOI : 10.4000/ema.1047

ISSN : 2090-7273

\section{Éditeur}

CEDEJ - Centre d'études et de documentation économiques juridiques et sociales

\section{Édition imprimée}

Date de publication : 30 juin 2005

Pagination : 145-158

ISSN : 1110-5097

\section{Référence électronique}

Barbara Drieskens, « What happened? Stories, judgements and reconciliations », Égypte/Monde arabe [En ligne], 1 | 2005, mis en ligne le 08 juillet 2008, consulté le 07 juillet 2022. URL : http:// journals.openedition.org/ema/1047 ; DOI : https://doi.org/10.4000/ema.1047

Ce document a été généré automatiquement le 7 juillet 2022.

Tous droits réservés 


\title{
What happened? Stories, judgements and reconciliations
}

\author{
Barbara Drieskens
}

\section{What happened?}

1 In legal cases, one of the pressing questions is always "What happened?", and the authoritative version of the event is constructed during the judicial process of negotiations and questioning. Such an officially established version of the event can form the basis for the judge or intermediary party to evaluate the behavior of the concerned parties either as normal, that is, according to the norms, or as deviant, transgressing the rules of social order or law, but it can also be the version that best fits the particular aim of recounting the event in a specific context. ${ }^{1}$ The accepted version functions first of all as means of mobilizing support from the group, but also serves to define and demarcate the two opposing parties, and to negotiate the different positions within the family and the [question of the] family's reputation. Stories about conflicts and legal transactions often continue to be meaningful for many years after the formal solution of the case. These stories usually change during that time and are adapted to the changing relations between the parties that were involved. They often feature as important elements in the construction of a reputation or in the justification of behavior and choices.

2 Stories about conflicts are often part of the family stories and are regularly reactualized. Sometimes they describe just the conflict itself; some versions end with the formal solution of the conflict, while others extend over a long period until the moment when the narrator feels that justice has been done. They continue to be meaningful for many years, even if their meaning can change dramatically. ${ }^{2} \mathrm{This}$ article follows such a story from the beginning of the conflict, through the changes during negotiation and the evaluation of the solution, until it underwent another transformation caused by new events five years later. 


\section{The fight in Bashtil}

3 Immediately after the events, the first version of the story is recounted by those who saw what happened, who experienced the facts personally, but very soon this is taken up by their family, friends and neighbors as well. Usually the story begins at the moment when things started to go wrong. It is, however, rarely told as a whole, since most of the time people lift out certain elements and start with the dramatic moment: "My brother was wounded in a fight and went to the hospital." It is then up to the listener to ask the right questions to find out the rest of the story. ${ }^{3}$ Storytelling in Cairo takes place in an encounter where both listeners and narrator play an active role. The listeners are not only supposed to ask the right questions to trigger off a story, but also to encourage the storyteller with their exclamations, comments and gestures, pushing him or her to perform better, to appear more credible and to introduce sudden unexpected turns to impress and surprise the audience. A story that does not affect the listeners emotionally is considered to be a failure. ${ }^{4}$ Telling the story of the fight in Bashtil was for the narrator a way to express anger and indignation, but nearly always it was also a way of mobilizing support.

4 Ahmed owned a shop in Bashtil5and his eldest brother, Mohsen, took care of it. Mohsen's brother-in-law assisted him, and that day there was an argument in the shop between this young man and someone from an influential saî̀ $\hat{\imath}$ family (the Bani Mohammed). Mohsen tried to calm both parties, but a man from the other family hit him on the head with a stick and Mohsen was taken to hospital, where he had stitches for his wound.

5 Mohsen's mother played the most important role in mobilizing the rest of the family, and the story started to turn into a powerful accusation of the offender's family by adding some details and emphasizing certain elements. By means of the story, she tried to induce sympathy for her son and to convey feelings of anger and injustice by presenting him as the benign fellow whose intentions were only good. It was, however, important not to represent him purely as the passive victim, the one who should be pitied, because such a presentation of the event would lower respect for Mohsen:

Mohsen wanted to calm both parties and tried to protect his brother-in-law, who was a young man from the Dakhla oasis. He approached the client with a conciliatory gesture to soothe his anger when this other man [who was] from the sa'îlî family hit him with a stick, from behind. The next moment blood was dripping from Mohsen's wound and he was taken to the hospital where he had ten stitches.

6 Essential to this story was that Mohsen did not provoke the others; that his intentions had been nothing but good and he did what he was supposed to do. When two people fight, the onlookers should calm them and Cairenes say that the best way is to hug the more aggressive one of the two, because a hug soothes his anger and in the same time prevents him from harming others. The emphasis is here on the normality ${ }^{6}$ of Mohsen's behavior: he did what anyone would do and what should be done, in contrast to the man from the Bani Mohammed family. Mohsen appears neither as passive nor fearful, and therefore his role as a victim should not diminish respect for him, but arouse indignation.

7 Since the fight was between a strong saî̀ $1 \hat{\imath}$ and a young man from the oasis, it was evident to both narrator and listeners that it was the saî̀ $\hat{\imath}$ who had to be quietened 
down first. The specification that Mohsen's brother-in-law was from the oasis and the opposing party from Upper Egypt (sa'îli's) is very meaningful for the listeners. The stereotypes that Cairenes attribute to these categories are that men from the oasis are small and slender, while saîlil's are quick tempered, aggressive and strong. To make sure that they understood the meaning behind these descriptions, Mohsen's mother stressed her words with a gesture indicating how small and slender the young man was compared to the large and tall sa'îdî. The gestures helped the audience to imagine 'what happened', but in the storytelling encounter the listeners too showed their involvement by making gestures of astonishment (opening their hands) and of distress (touching their heart or faces).

8 In the first days after the fight there were still other versions of the story. Mohsen suggested that his conciliatory gesture might have appeared as if he was going to attack the other man. He was also not so sure where the second man who attacked him came from; he had not really seen him. The argument between his brother-in-law and the client was not very clear, but when his brothers recounted the event these elements were omitted, and soon all these uncertainties were flattened into an accepted version of the facts.

When Mohsen's mother told the story to other women, she emphasized her son's suffering not to make them pity him, because an adult man should not evoke pity, but to make them pity her as a mother, that she had had to see her son being treated in this way. When she recounted the story to male relatives, the accent shifted towards the issues of honor and blood. The versions of the event that were established were not necessarily the most "true" stories in a referential sense. They were those that worked best, that affected the audience more and better than others, and where credibility and emotional impact prevailed over the referential aspect.

The blood and the stitches were important elements, since harming someone's blood not only means harming his physical integrity, but also touches on the honor of the whole family. ${ }^{7}$ When blood flows by accident in a playful fight, it is still possible to ignore it, but when it is caused by a deliberate act, with the intention to harm and without serious provocation, it is a stain on the integrity of the entire family. In addition, there was the fact that it was not presented as an equal, open fight between two men facing each other, but as a treacherous act where an innocent, unaware man was attacked from behind. The behavior of the other party is presented as unseemly and deviant. In her emphasis on these elements, Mohsen's mother tried to secure the support of the family's male relatives, as well as to gain the sympathy and empathy of her own former colleagues. Many people came to visit and offered their assistance. The story not only mobilized the family, but also reinforced its social network.

\section{During negotiations}

11 The incident triggered off a round of negotiations, and everyone in Mohsen's family had his or her opinion. They discussed whether revenge or reconciliation was more appropriate, who should be the spokesman of the family and whether they should go and talk to the other family or just wait. Now that the different versions of "what happened" had mobilized quite a lot of family members to stand by them, the question was what to do next. In the discussions about the right way to react, the story still played an important role, no longer in constituting a persuasive and credible version of 
the event, but in defining the two parties - "them versus us". The issue was not only who the Bani Mohammed were, but also how Mohsen's family was going to organize and present itself. The stories about both families started from the moment the first members came to town. Even if the village of origin was regularly mentioned, what happened before coming to Cairo did not count in these stories. ${ }^{8}$

The two saî̀î men were from the Bani Mohammed, a family from Upper Egypt who claimed to be of arab origin. They had just moved into town. One of them, Mohammed, came some years ago and started a coffee house in Bashtil and became rich and successful, and many of his brothers and cousins followed him, until they grew into the most powerful and influential family in the neighborhood. Anyway, they were not the right people to enter into discussion with and certainly not to fight with.

12 The term sa'îdî refers to the people from south of Cairo, and sa'îlî̀s are the preferred subject for jokes and stories in which they appear as stubborn, slow of understanding and with closed minds (Ireton, 2000). Nevertheless, the saî̀dî are proud of their descent, because saî̀ î also implies honorable, straightforward and observant of tradition. Also, Mohsen's family was originally from the south and it was their grandfather who first came to the capital. Although their descent and their long presence in the city entitled them to as much respect as the Bani Mohammed, Mohsen's family was largely outnumbered by the Bani Mohammed and also lacked their economic power.

People said that the Bani Mohammed became so influential in the neighborhood because they cooperated with the police. Some years before there had been problems in Bashtil with Islamic groups, gamâât, and people said that the Bani Mohammed had reported quite a lot of Islamic activists to the police. They still had a good relationship with the Egyptian authorities, and this is what had made it possible for them to grow so powerful in such a short time.

It was, however, important for Mohsen's family to appear as equal to, or even better than the Bani Mohammed. Emphasizing certain aspects could lower the prestige of the Bani Mohammed, while other aspects could compensate for their economic success and authority. The inequality of the two parties was accentuated in order to explain why Mohsen's family did not react immediately, but it was always followed by the explanation that this was not Mohsen's reason for not appealing to state law. During the negotiations within Mohsen's family about the right solution for the conflict, they regularly stressed that it was not fear that restrained them from making an official statement, but rather their concern with honor and tradition. They elaborated on their motives when explaining the conflict to others, preferring to show the differences and discord within the family rather than to appear as fearful and weak. In the storytelling process, the motives for people's choices are important for the way in which they are judged by others, and stories can be very helpful in explaining certain choices as conforming to ideals of courage and tradition:

Mohsen's grandfather came to Cairo, and Mohsen's father was a general in the police force. He brought many men from the village to Cairo to stand by his side and provided them with a good jobs, like Mansi who worked as a civil servant. He died young, and his four sons were all still too young and inexperienced to take his place as the elder (al-kabir) of the family in Cairo.

The question of who was going to represent Mohsen's family was one of the central points in the stories and discussions among both men and women in the family. This choice was also to a large extent connected with the decision about the course of action. Mansi seemed convinced that it was his right and duty to take the role of elder, 
but Ahmed, Mohsen's brother, considered that he himself now had the age and the right to take this place that formerly belonged to his father. Within the family there was much disagreement about who should represent them and what their line of action would be. The stories about their village and their 'arab origin helped to put things in balance and to establish some feeling of belonging together. Three elements were central to defining their identity as a family and determining their choices: origin, honor and authority.

The 'arab origin of Mohsen's family featured as a central argument in the family stories that were recounted at the time of the conflict. In this context, their 'arab origin was not traced back to the tribe of the Prophet, as one of the older men had done on other occasions (for example, in a religious context, talking about the mûlid of al-Hussein ). Now, they referred to the tribe of the Huyatat and to a Yemenite origin. Mohsen's oldest brother, Ahmed, in particular liked to describe his traveling in Yemen:

When I was in Yemen I often met people who looked exactly like me. I had the feeling of standing eye to eye with an unknown brother. They are of the same tribe and still live like our people used to do. Every man carries a weapon, and they follow only the tribal laws without any interference from the government.

The family referred to this 'arab origin not only to emphasize the need to resolve this conflict honorably, but also as a determining factor in their choice between state law, customary law and revenge. State law was excluded as an option when their 'arab identity was brought forward. They said that the state law was foreign, French law and did not suit their traditions and beliefs. According to them, Arabs solved their problems among themselves and did not need an outsider to intervene in their conflicts, especially when the opposing party was also of 'arab origin.

In a discussion where Arab honor (sharaf) was the issue, then revenge (tha' $\left.r^{9}\right)$ was the solution they proposed as the only way to reestablish their honor, and they told stories of villages in Upper Egypt where only the women asurvived after revenge killings, and also carried weapons. These stories were not presented as fearful examples of the consequences of retaliation, but as proof that this was the way that genuinely honorable families solved their conflicts when satisfactory reconciliation was impossible. Only when the blood of the other family flowed in the way that their own blood had been shed would the stain on their honor be washed away. There were, of course, a lot of counter-arguments against this solution, since it risked escalating into an endless feud between two families and could also lead to problems with the state authorities. At this point Mohsen's mother intervened with stories about her deceased husband, who was a police officer and always tried to solve problems honorably without going against state law.

Ahmed was very much in favor of retaliation, but sometimes the extreme nature of his ideas seemed motivated more by his resistance to Mansi's influence in the family. When Mansi talked about reconciliation, Ahmed mentioned the disgrace of accepting money in return for blood, but when 'arab custom was invoked, then reconciliation, sulh (Khadduri, 1998 ; Ben Néfissa, 1999 ; Korsholm, 1998) could nevertheless be considered as the suitable solution:

If we had been in the village, where 'arab custom still prevails, the family would threaten serious revenge until the Bani Mohammed came to ask for reconciliation, and the elders would mediate in the negotiations between the families and the offender would have to pay compensation for the damages. Custom would be respected and the honor of the family would be preserved. 
This explanation about custom ('urf - Ben Néfissa, 1999 ; Korsholm, 1998) and honor (sharaf) was formulated not only for my benefit, as I was unfamiliar with these traditions, but was also presented among Mohsen's brothers as an ideal that was very different from the actual context of the city. Of the four brothers, only Sayid had visited the home village, and until the time of the conflict no one had ever mentioned the 'arab origin of the family in my presence. The negotiations about the right way to handle the conflict lasted for several days, and everyone in the family had his or her say, using elements from the story to support an argument in favor of revenge, reconciliation or state law. ${ }^{10}$ What was very much at stake in these discussions was the reputation of the family; how others would treat them afterwards in the neighborhood; whether they would respect them; and what they would say about the fight and its solution.

It seemed that the confusion of the city, where traditions were mostly lost or had changed, and were adapted pragmatically to the mixed context of the suburbs, added to the uncertainty in Mohsen's family about what line of action to adopt. In the days following the fight, a cousin came from their village of origin to stand with them in the conflict and to represent the support of the family in the village. His stories about reconciliation and revenge constituted a reference, and were soon recounted by the brothers as if they had seen these practices of reconciliation and revenge themselves. The way things were done in the village became an ideal, and brought agreement among the different factions in the family. Ahmed finally accepted reconciliation as a solution, and the authority of Mansi, at least in front of the Bani Mohammed.

\section{After the formal solution}

More than ten men came from the village on the day that the conflict was publicly settled by the handing over of money and acceptance of apologies. The Bani Mohammed also showed up in large numbers for this very short ceremony, where the threat of physical violence united the two parties behind their spokesmen (alkabir). One wrong move or disrespectful word would have been enough to trigger a fight.

21 When Ahmed told the story of the conflict, he underlined the equal positions of both families and the fear that his family aroused among the Bani Mohammed. He referred to 'arab traditions and insisted on the fact that they were from the tribe of the Huyatat, which belonged to the honorable 'arab, the Shurafâ. ${ }^{11} \mathrm{He}$ also added that he had always been in favor of retaliation, and did not consider the formal solution of the sulh to be binding. He expressed his desire to take revenge by hitting a man of the Bani Mohammed in the same manner that Mohsen had been hit.

Mansi liked to stress his personal role in solving the conflict. Thanks to him, he would indicate, Mohsen's family was able to face the other family as equals. He was the only one of the family who had still regular contacts with the people from the village where his brothers lived. He boasted about his knowledge of customary law, and referred to previous conflicts in Bashtil where he had mediated between the parties. He liked to mention how he had been able to convince the Bani Mohammed to show the family due respect.

Mohsen's mother told the story quite differently. For her, the cause of all the trouble was the shop. Even before the fight it had been the cause of discussion and discord 
among her sons, and its situation in a vulgar (baladi) neighborhood, made it more of a burden than a blessing:

Already some months before the conflict troubles started with this shop. Sayid, Mohsen's brother, was supposed to help him but he could not stand the pressure and responsibility. He is from a good family and therefore not used to dealing with vulgar people day and night. He started to take pills to forget his misery, until the family decided that he had better stay at home. This is when Mohsen's brother-inlaw began to assist him, and this was the cause of the fight of which Mohsen became the victim.

Every time she saw one of her sons she repeated this story, ending with the conclusion that it would be much better to sell the shop as soon as possible. Ahmed said that her opinion was influenced chiefly by her economic situation and her need of cash, and that she saw the incident as an ideal occasion to solve various problems at one and the same time.. However, in the end he gave in to his mother and the shop was offered for sale. For Ahmed, this was one step in what he considered to be the right direction. He wanted his brothers, Mohsen and Sayid, to leave Bashtil and move to another neighborhood, after which it would be possible to wipe the stain from the family's honor by taking revenge.

Rania, Mohsen's sister, warned the others not to overlook the long-term effects of the fight. She feared that Mohsen would suffer from the fact that he had acted in full confidence and with good intentions when he was attacked, and that this would have psychological consequences in the long term. When Mohsen suffered from high blood pressure several years later, Rania brought up the story of the conflict as an explanation and pointed out that these were the consequences she had warned them about at the time.

\section{An unsatisfactory solution}

Officially, the whole case was over after the acceptance of the reconciliation. The conflict came to an end and Mohsen gave up the right to take revenge; but in the discussions between him and his brothers the problem had not disappeared. There were different reasons to appreciate or criticize what had happened, and different principles were resorted to when evaluating the event. First of all, they argued about justice and whether or not right (haqq) had been done. Reputation and respect also played a role in the assessment of the event, which, according to some, was a missed opportunity to establish their reputation firmly in the neighborhood. Their authority, or economic and social influence, was a third factor that determined their appreciation or criticism of the solution.

In general, they were not satisfied with the outcome of the conflict. The Bani Mohammed had given some money as compensation, but the sum was less than they had expected and it hardly covered the medical expenses. They complained that a similar conflict in the village, with a traditional sulh, would have brought them more than double. They repeatedly mentioned how in the village a group of elders would have constituted an intermediary party to mediate between the two families, and that would have determined the right amount of money to be paid by the Bani Mohammed in compensation. In Mohsen's case, on the other hand, they had had to negotiate directly with the offender's family because there were no men in Bashtil whose authority and impartiality was accepted by both parties. Mansi and Mohsen's brothers 
had considered it inappropriate and dishonoring to ask for money in the negotiations with the other side, and had preferred to trust that the Bani Mohammed knew what should be done in these circumstances.

Another reason for their discontent was that it soon became clear that they had lost quite a lot of respect in the neighborhood. Mohsen felt that he was not treated in the same way as before. He experienced daily confrontation with the Bani Mohammed who were growing more and more influential and rich - as a humiliation, and his brother Sayid even went as far as to forbid his wife to shop in the market on her own. He did not want her to go out without him for fear that men would not treat her with the necessary respect.

Only a short time after the fight the family sold the shop, but the Bani Mohammed boycotted the sale and frightened off prospective buyers. They were becoming very powerful in the neighborhood and nobody dared to do anything without their approval. The eventual sale price of the shop was less than its value. This left a bitter taste, and in its discussions the family blamed the conflict with the Bani Mohammed as the reason behind both the sale of the shop and its low price.

The story of the conflict was often used to explain and validate certain positions within the family. Depending on the context, different people were blamed for the fight and its unsatisfactory solution, and by casting the blame on certain actors, distinctions could be created between 'them and us"(ihnâ wa ghayrnâ). Here, too, stories about what had happened were inconsistent, and different forms of blame such as greed, bad manners and personal interest were attributed to different actors. Abu Lughod (1997: 542-543) mentions similar discrepancies between the different stories about a death among the Awlad 'Ali Bedouins from the Western desert and various forms of blame (in this case stupidity, reputation and the evil eye). In general they made a distinction between the individual who was a cause (sabab) of the event and the responsibility (mas'uliyya) for what happened, which was collective. As an excuse, the blame was often attributed to the circumstances (al-zurûf) - the situation in the neighborhood and the degeneration of social norms.

Mohsen's mother said that the cause of the conflict lay with Mohsen's wife and her brother, that she was very greedy and forced Mohsen to combine his job as a civil servant with the work in the shop, and that even that was not enough for her. She had wanted her family to profit as well and convinced Mohsen to hire her brother, while the events proved that he was not a suitable person to do this job. If he had not been rude to the client and if he had been able to stand up for himself, Mohsen would have never have been put through all this humiliation.

31 Whenever the brothers complained about a shortage of money, they referred to the good days when their salaries were augmented by the income of the shop, and Mohsen's family-in-law was blamed as the cause of all their trouble. When Mohsen was in discord with his wife, his mother used the story of the conflict to strengthen her son's position and to judge his wife's behavior as unseemly and wrong. Mohsen's mother had never accepted Mohsen's leaving the middle class neighborhood of Abdin to go and live in the suburbs of Bashtil, and disapproved of his decision to complement his salary of civil servant with the commercial activities of the shop. This "degeneration"was all blamed on his wife and her family:

Mansi was the reason that the Bani Mohammed did not show them the due respect, because he used the conflict to increase his influence and authority in the family and in the neighborhood. He accepted the sulh to show his own willingness and 
generosity towards the Bani Mohammed, and was not able to induce enough fear and respect to make them pay a decent sum of money. He tried to be both a mediator and the elder of Mohsen's family, and this is how he lost the chance to gain prestige and respect.

They blamed the unsatisfactory sulh on the weakness of Mansi, who in this context was often considered an outsider in the family. In these discussions they did not call him "am Mansi" (uncle Mansi) as they used to do, but just Mansi. When he went to confront the Bani Mohammed his task was to represent Mohsen's family, and as such he should have presented their demands in a way that commanded respect and fear. Because he had been a mediator in previous conflicts between unrelated families, he wanted to take this role again. From Korsholm Nielsen's description of customary law in the region of Edfou, we see that conflicts are usually mediated by a third party made up of influential but impartial men who constitute the maglis al-urfi, the assembly that imposes a judgement on the two sides in conflict. Here there was no third party, and the Bani Mohammed did not expect the representative of the other family to be very understanding of their arguments, or that he would try to soften the positions of both antagonists. Mansi was the one who mobilized the men from the village and in this way made it possible for both families to meet as equals, but as he tried to be the mediator as well as the representative of one of the parties, he compromised the opportunity he created to come out of the conflict with enhanced honor and respect for the family.

Ahmed used this story of failure to lessen Mansi's authority within the family and to challenge him for the position of elder. He presented Mansi as the cause of the unsatisfactory sulh, and stressed that from the beginning he had objected to his choice of reconciliation as well as to his role as the family's representative. By presenting Mansi as a failure, Ahmed strengthened his own position in the family.

Mohsen was in fact both victim of as well as responsible (mas' $\hat{u}$ ) for what happened. As the oldest of four brothers he should have known better than to hire his brother-inlaw. However, in this his brother Sayid was at fault (ghaltân), because he should have assisted his older brother in the shop rather than staying at home. Mohsen was also the one who chose to live in Bashtil, while his mother and his sister had always advised him against it. Mohsen, as the oldest of the brothers, was responsible and had to bear the consequences of his choice, but fate had punished him severely, while the ones who were really responsible were of course the elders of the Bani Mohammed. They did not accept their responsibility and did not make up for the mistakes committed by family members:

It is beyond doubt that the young man who hit Mohsen with a stick on the back of his head is the one [who was] mistaken (ghaltân). He started a fight over a triviality.. However, the ones who are responsible (mas'ûl) are the elders of the family, who brought up their young men without manners and who did not respect the rules of reconciliation. In fact, the Bani Mohammed are not real 'arab; if they were they would have paid the right amount of money as prescribed by tradition.

Here the blame and responsibility of the conflict and its outcome is situated completely outside the family. This appears as quite a typical characteristic of Cairene stories. A story of a particular event can be used to adjust positions within the family, to enforce authority or to blame others for their weakness; but ultimately the blame is always placed on the other, the one who is outside the family or group. Stories about conflicts are often used to enforce blood ties and to protect the family's reputation. When members of Mohsen's family told the story they frequently highlighted their own 
reputation as real 'arab, versus those who did not know tradition, and as well-educated men versus those with bad manners. They used the fact that the Bani Mohammed paid very little as compensation - much less than in traditional sulh - as a reason for presenting them as 'not real 'arab', arguing that despite their authority in the neighborhood the respect for them was based only on physical strength and economic power, lacking manners (akhlâq) and descent ('arab).

\section{Divine justice}

Almost five years after Mohsen's conflict another serious conflict occurred in Bashtil. It started quite innocently as a fight between children, two boys, of whom one belonged to the Bani Mohammed. The other boy had insulted the grandson of one of the elders of the Bani Mohammed. After he went home, two young men of the Bani Mohammed came to this boy's house to look for trouble, but the family were well prepared for the confrontation and pulled their knifes and killed one of the Bani Mohammed boys. The neighbors called the police and the killer ran and hid, but his smaller brother, who had started the fight, was taken into the police van for interrogation. On the way to the police station some men of the Bani Mohammed stopped the police van, and held the police officers at gunpoint while they slaughtered the boy before their eyes.

For Mohsen's family this only served to reinforce their own account about the quicktempered saîlî family and the danger they presented to social order. It confirmed that the Bani Mohammed had no respect either for customary law (in Mohsen's case), or for state law (in the new case).

All the men of the Bani Mohammed, except the very old and the children, fled to the countryside. The police searched their houses, confiscated 42 weapons and even arrested their mothers in order to force the men to hand themselves over. Most of the shops in the neighborhood belonging to the Bani Mohammed closed.

When this story reached Mohsen and his brothers they were all very much relieved, because finally their honor had been reestablished and the injustice paid for. That this did not happen by their hand was no objection - on the contrary, it was a sign of divine justice. Only after the fall of the Bani Mohammed was the story of the fight of Mohsen referred to as a closed case, and even Ahmed stopped talking about revenge. This did not mean, however, that the story ceased to be meaningful. It was recounted several times, but no longer to distinguish between different groups within the family, or between Mohsen's family and his in-laws, or between them and the Bani Mohammed. It became an exemplary story of divine justice and a way to comfort others who felt they had been unjustly treated.

\section{BIBLIOGRAPHIE}

BEN NÉFISSA S., 1999, “The Haqq al-'Arab: Conflict Resolution and Distinctive Features of Legal

Pluralism in Contemporary Egypt”, in Dupret B., Berger M. and al-Zwaini 
L. (eds), Legal Pluralism in the Arab World, Kluwer Law International, The Hague, London and Boston. BiBARS I., 2001, Victims and Heroines: Women, Welfare and the Egyptian State, Zed Books, London and New York.

Dor A.R.I., 1984, Shari'ah: The Islamic Law, Ta Ha Publications, London.

Dupret B., 2003, "The Person in an Egyptian Judicial Context: An Ethnomethodological Analysis of Courtroom Proceeding," International Journal for the Semiotics of Law, 16 (1).

EARLY E.A., 1985, "Catharsis and Creation: The Everyday Narratives of Baladi Women of Cairo", Anthropological Quarterly, 58.

Ghannam F., 2000, "Re-imagining the Global: Relocation and Local Identities in Cairo", in Miles M., Hall T. and Borden I. (eds), The City Cultures Reader, Routledge, London and New York.

HIRSCHKIND C., 2001, "The ethics of listening: cassette-sermon auditions in contemporary Egypt", American Ethnologist, 28 (3).

INHORN M.C., 1996, Infertility and Patriarchy: the Cultural Politics of Gender and Family Life in Egypt, University of Pennsylvania Press, Philadelphia.

IRETON F., 2000, "Les quatre relations d'incertitude d'un construit identitaire collectif à référence territoriale : l'exemple des Sa'îdîs", in Décobert C. (ed.), Valeur et distance : Identités et sociétés en Égypte, Maison méditerranéenne des Sciences de l'homme, Maisonneuve et Larose.

KHADDURI M., 1998, Sulh. EI2, IX.

KoRSHOLm Nielsen H.C., 1998, "Négociation et écriture : à propos du droit coutumier en HauteÉgypte", Égypte/Monde arabe, n³4.

MacLeod A.E., 1991, Accommodating Protest: Working Women, the New Veiling, and Change in Cairo, American University in Cairo Press, Cairo.

Mernissi F., 1985, Beyond the Veil: Male-Female Dynamics in Modern Muslim Society, Al Saqi Books, London.

SAAD R., 1996, "Situer le village égyptien : la recherche d'une identité représentative”, Égypte/ Monde arabe, $\mathrm{n}^{\circ} 25$.

Stewart F.H., 1987, “A Bedouin Narrative from Central Sinai”, Journal of Arabic Linguistics. -, 1994, Honor, University of Chicago Press, Chicago and London.

\section{NOTES}

1. Conley and O'Barr (1990:10) argue that a dispute has no concrete existence independent of the accounts that constitute its expression, and that at any particular point in time the dispute is the account being given at the time.

2. Stewart (1987) also analyses a Bedouin narrative about a conflict, but does not situate it in the storytelling encounter, where much more is at play than simply an account of what happened.

3. The stories I mention here are not direct quotes from the Cairene stories. In the context of conflicts and negotiations within the family it was impossible to use a tape recorder, and they were written down from memory a few hours later.

4. See also Early (1985) and the description of the techniques of affecting an audience in a religious context: Hirschkind (2001). 
5. Bashtil is part of Imbaba, one of the suburbs of Cairo, with a population of very diverse geographical and social background.

6. Dupret (2003), p. 15-44, describes normality both as a statistical and a prescriptive notion, and rightly notes that this category is not pre-existent beyond a particular context, but is, on the contrary, shaped and constituted through its use in different contexts.

7. The concept of honor is in Middle Eastern studies is often restricted to patriarchy and the control of men over the behavior of the women who are related to them (Inhorn, 1996:42, Bibars 2001:157, Mernissi, 1985:183). Harm that affects the physical integrity of a person is, however, just as much an issue of honor and concerns the whole family, men and women alike. See also Stewart (1994).

8. About the continuity between village and town, see Saad (1996). Ghannam (2000:188) shows how a Cairene neighborhood could take the place of the village as a point of reference, in a particular context of dislocation.

9. Tar or tha'r in standard Arabic is the technical term for blood revenge or retribution under tribal law. Under Islamic law the term is qisâs, and applies both to homicide and bodily harm (Doi, 1984).

10. To present a more balanced version of the event, it would be necessary also to include the versions of the conflict as told by the Bani Mohammed and the version that both parties agreed upon when they negotiated reconciliation. In these negotiations, only Mohsen and his two oldest brothers, Ahmed and Sayid, were present, together with Mansi, who took the role of the elder of the family (al-kabîr).

11. The shurafâ, are presented as the honorable 'arab, those who descend from the first Islamic tribes from Saudi or Yemenite origin and who live according to the 'urfi law.

INDEX

Mots-clés : droit

\section{AUTEUR}

\section{BARBARA DRIESKENS}

IFPO 